\title{
Just fatherlands? Judging the Shoah in Strasbourg.
}

LYONS, C.

2022 


\title{
26
}

\section{Just Fatherlands? Judging the Shoah in Strasbourg}

\author{
CAROLE LYONS"
}

\begin{abstract}
In the twentieth century, there will be an extraordinary nation. It will be a great nation but its grandeur will not limit its freedom. It will be famous, wealthy, poetic, cordial to the rest of humanity ... it will be called Europe. Europe ... will be called humanity. Humanity, definitive nation ... what a majestic vision $!^{1}$
\end{abstract}

\section{INTRODUCTION}

HE PRIMARY PREOCCUPATION of this chapter is an examination of how Europe's highest human rights court works through the enduring effects of the 'moral catastrophe' of the Holocaust. ${ }^{2}$ The issue of the role of past inhumanity within Europe's present is fundamental and informs (or ought to) the ways in which justice is done and understood in Europe as a whole. This chapter concentrates on one judicial forum, the European Court of Human Rights (ECtHR), and the continuing influence of the Holocaust/Shoah within its jurisprudence. The focus on a particular past in the evolution of European human rights raises general questions as to how history and memory are mediated through the judicial route and, more specifically, how the legacy of Auschwitz has helped to mould the human rights culture which now guides 47 European states, including the $28 \mathrm{EU}$ Member States. The importance of mutual dependency of the EU States has been raised by other contributions to this volume. This chapter suggests that such mutual dependency would be difficult to arrive at in the absence of a parallel mutual confrontation of the past. Mutuality and solidarity, written into, if not consistently respected within, European integration, are rooted in an implicit shared, European responsibility for the shaping of an ethical response to institutionalised racist killing. András Sajó, in his chapter in this collection, discusses the concept of the 'responsible

* With much gratitude for the generosity of Gráinne de Búrca, Dimitry Kochenov and Andrew Williams.

1 V Hugo, 'L'avenir' in Paris (Paris, Introduction to the Paris Guide, 1867) 11 cited in J Derrida, The Politics of Friendship (London, Verso, 1997) 264.

2 J Habermas, 'Democracy, Solidarity and the European Crisis' lecture at KU Leuven (26 April 2013), www.kuleuven.be/communicatie/evenementen/evenementen/jurgen-habermas/en/democracy-solidarityand-the-european-crisis. 
community' in respect of past injustices and how that responsibility equates to 'patrolling our moral borders'. ${ }^{3}$ Applied to integration processes in Europe it might be posited that the European (responsible) community has Greece (and all the other EU Member States) absorb Germany's past shame, ${ }^{4}$ while Germany assists debt recovery in Greece. The constantly alluded to, but nonetheless nebulous, acquis communitaire which governs the EU integration compact, is not exactly explicit on such a distribution of debt and disgrace. ${ }^{5}$ Turning to European human rights processes specifically, although it might be questioned how much the 'just fatherlands' 6 anticipated while the European Convention on Human Rights (ECHR) was being drafted in 1950 have been achieved, the ECtHR is a forum where an encounter with the past has been taking place, to a greater or lesser extent, for over 50 years. Judge Sajó's chapter asks us to re-examine accepted notions of victimhood which lie at the root of the judicial approach to past collective injustices. This chapter offers a pragmatic complement to that thesis in identifying the stages of Holocaust-specific case-law from Strasbourg and placing an analysis of that Court's approach to the Shoah in the context of a consideration of the extent and nature of a justice deficit in the European legal space.

Digging up the past is all the rage these days. Literally, in the case of King Richard III in a Leicester car park ${ }^{7}$ and Federico García Lorca in Andalucia ${ }^{8}$ but, more significantly, in the continuing search for those responsible for past injustices such as Hungarian Nazis in an Australian court, ${ }^{9}$ Spanish Judge Baltasar Garzón's (ill-fated) pursuit of civil war crimes against humanity in Spain, ${ }^{10}$ multiple apologies for past wrongs, slavery, famines, ${ }^{11}$ even Wayne Rooney goes to

3 A Sajó, 'Victimhood and Vulnerability As Sources of Justice' in this volume, 337, at 340.

4 Habermas, 'Democracy, Solidarity and the European Crisis', $n 2$ above, on the continuing necessity of this 'exchange' for Germany.

5 The debt element of this 'bargain' has been addressed in the 2011-12 'six pack' and 'two pack' EU economic measures but without concomitant attention to social or historical context. See, generally, B de Witte, H Héritier and AH Trechsel (eds), The Euro Crisis and the State of European Democracy (Fiesole, European University Institute, 2013). Read a prosaic definition of the acquis communautaire at www.europa.eu/legislation_summaries/glossary/community_acquis_en.htm.

6 'I think that from our First Session we can unanimously proclaim that in Europe there will henceforth only be just fatherlands.' Pierre-Henri Teitgen, addressing the Consultative Assembly of the Council of Europe, Strasbourg, August 1949, discussing the drafting of the European Convention on Human Rights. He was recalling his father's memory of an inscription on the gates at Buchenwald concentration camp which read 'Just or unjust, the Fatherland'. MW Janis, RS Kay and AW Bradley, European Human Rights Law: Text and Materials (Oxford, Oxford University Press, 2008) 14.

7 The body of the last king of England to die in battle (in 1485) was discovered under a car park in Leicester in 2012: www.le.ac.uk/richardiii/.

8 'Spanish judge orders poet García Lorca's grave to be opened' The Guardian (16 October 2008), www.theguardian.com/world/2008/oct/16/lorca-grave-spain; and 'Lorca mystery may soon be solved but much of Spain's past remains buried' The Guardian (1 December 2014), http://www.theguardian.com/ culture/2014/dec/01/-sp-garcia-lorca-mystery-solved-spain-remains-buried.

9 Minister for Home Affairs of the Commonwealth v Zentai [2012]. HCA 28 (15 August 2012).

10 'Baltasar Garzón cleared over his Franco-era crimes inquiry' The Guardian (27 February 2012), www.theguardian.com/world/2012/feb/27/baltasar-garzon-cleared-franco-crimes.

11 Such as Prime Minister David Cameron's apology for the killings of civilians in Northern Ireland in 1972 (www.bbc.co.uk/news/10320609) and Prime Minister Tony Blair's apology for the Irish Famine of the 1840s (www.bbc.co.uk/news/uk-northern-ireland-17124401). 
Auschwitz. ${ }^{12}$ Times change; the culture of commemoration (and confession), now so popular and populist, was sidelined for many years of the twentieth century. ${ }^{13}$ Dealing with and genuinely facing up to the past is another matter, long ignored in European legal analysis but now taken more seriously. ${ }^{14}$ It is trite to note that any entity which seeks to progress needs to be aware of its history but, nonetheless, this banality does expose a dearth at the core of unity and integration in Europe. The Council of Europe, the EU and their institutions have devoted scant space to the development of a formal recognition of the past which could ethically underpin the highly contested future of European integration. As if from terra nullius born, the shiny structures of European unity largely ignored their sombre origins. As András Sajó remarks, 'The current European system is based on assumptions generated by the experiences of World War II ... a genuine concern about victims of past injustice emerged within this frame, but only relatively lately and with a great deal of hesitation .... ${ }^{15}$ This lacuna cannot but impact upon the nature and the extent of justice emanating from European institutions.

Andrew Williams, who has written of the 'uncertain soul of Europe', ${ }^{16}$ has highlighted the failures of the human rights systems in Strasbourg, heralding a new awareness beyond the conventional appreciation of the ECHR and its Court. These failures are not only at the all too well-known structural, practical level; ${ }^{17}$ rather, it is the 'broken dream', 'the disjuncture between the moment of the text, its genesis and the reality of its ... application'. ${ }^{18}$ The ECHR was drafted in the shadow of the Shoah yet has no regard to institutionalised killing or genocide. ${ }^{19} \mathrm{He}$ argues that, in ignoring the reality of the Holocaust and absent the recognition of its relationship with the new human rights regime, 'the Convention was a singular failure'. ${ }^{20}$ What is at issue is 'the conceptual purpose' of this foundational text; 'the Convention has

12 Wayne Rooney is a footballer who plays for Manchester United and England, 'England players visit Auschwitz and meet Holocaust survivor' The Guardian (8 June 2012), www.theguardian.com/ football/2012/jun/08/euro-2012-england-players-visit-auschwitz. The issue of footballers' appreciation of the Holocaust and anti-Semitism has arisen also in the case of Nicolas Anelka making an anti-Semitic gesture (the so-called quenelle) during a football match in 2013: www.bbc.co.uk/sport/0/football/25870640. This contrasting behaviour was discussed in the UK Parliament during a lengthy debate to mark Holocaust Memorial Day (27 January in the UK and Europe), House of Commons Hansard Debates (23 January 2014), a remarkable debate which included a reading of Primo Levi's poem Shema.

13 The long awaited resolution of the claim of the families of thousands of soldiers murdered by the Union of Soviet Socialist Republics (USSR) in the forest of Katyń in 1940 offers a case study in changing perceptions about justice, memory and responsibility over the second half of the 20th century, Janowiec and Others $v$ Russia App Nos 55508/07 and 29520/09 [2014] 58 EHRR 30 (ECtHR (GC), 21 October 2013). See, generally, A Etkind, R Finnin et al, Remembering Katyń (Cambridge, Polity Press, 2012).

$14 \mathrm{Eg}$, the groundbreaking work of, inter alia, Vivian Curran, David Fraser, Christian Joerges and Tom Mertens.

15 Sajó, 'Victimhood and Vulnerability' in this volume, 337, at 338.

16 A Williams, The Ethos of Europe: Values, Law and Justice in the EU (Cambridge, Cambridge University Press, 2010) 1.

17 See, generally, S Greer, The European Convention on Human Rights: Achievements, Problems and Prospects (Cambridge, Cambridge University Press, 2006).

18 A Williams, 'Burying, Not Praising the European Convention on Human Rights' in N Walker, J Shaw and S Tierney (eds), Europe's Constitutional Mosaic (Oxford, Hart Publishing, 2012) 78; and A Williams, 'The European Convention on Human Rights, the EU and the UK: Confronting a Heresy' (2013) 24 European Journal of International Law 1157.

19 Williams, 'Burying, Not Praising', n 18 above, 79.

20 ibid. 
failed any conception of human rights that includes memorial goals' ${ }^{21}$ What might thus be termed the original sin of the ECHR system is then perpetuated; the entire system of human rights in Strasbourg is corralled by the ECHR, its content, its register, its limitations and the deficits which lie at it source. The Convention text rigidly frames, literally and analytically, the functioning of European human rights so much so that, instead of the now constantly debated institutional and structural reform, it might be apt to wonder if it is not time to cut up the map, à la Debord, and discover the text anew. ${ }^{22}$ Williams, too, ultimately suggests the need for a 'fundamental re-conceptualisation of the central purpose (or values) of human rights'. ${ }^{23}$

In the mid-1980s, in West Germany, a public debate took place between historians and philosophers engendered by Ernst Nolte's article in the Frankfurter Allgemeine Zeitung on 'The Past That Will Not Pass'. ${ }^{24}$ Termed the Historikerstreit, it provoked lengthy debate about what was seen as Nolte's apologia for the Holocaust and his intimation that a line be drawn under the Nazi past. Since that time, the opposite has arguably been the case; the dramatic political events of 1989, the new Germany and a generalised culture shift towards historical reflection, has resulted in an increased focus on the era of the Second World War. This has been reflected in the ECtHR in leading, recent judgments relating to mass executions in Poland $1940^{25}$ and partisan murders in Latvia in $1944 .{ }^{26}$ However, the ECtHR has not always been so preoccupied with events which predated its establishment. The Stunde Null mentality, which prevailed in Europe in 1945, passed over inaudibly to the early decades of the functioning of the new European human rights system such that the primordial era of case-law at the ECtHR was affected by a certain degree of historical amnesia. ${ }^{27}$ Thus, the judicial forum conceived with a view to ensuring 'the principle of collective responsibility for the maintenance of human rights'28 did not originally generate a supranational conscience to deal with what had been, de facto and de jure, supranational infraction. Bates identifies the major motivating force for the ECHR as a collective Western European pact against totalitarianism. ${ }^{29}$

21 ibid, 80 .

22 Guy Debord, in Psychogeographic Guide of Paris (Copenhagen, Permild \& Rosengreen, 1955) cuts up the map of Paris to facilitate a new perspective on and awareness of the city and take people away from the well-travelled, predictable routes. Following a Debordian line, you might say, further, that the European Convention represents the 'hard' or physical structure of European human rights whereas the Court's case-law is the 'soft', shifting element of Strasbourg justice.

23 Williams, 'Burying, Not Praising', n 18 above, 93.

24 See, generally, R Evans, In Hitler's Shadow: West German Historians and the Attempt to Escape From the Nazi Past (New York, NY, Alfred A Knopf, 1989).

25 Janowiec and Others $v$ Russia App Nos 55508/07 and 29520/09 (ECtHR, 16 April 2012) and, on appeal, [2014] 58 EHRR 30 (ECtHR (GC), 21 October 2013).

26 Kononov v Latvia App No 36376/04 (ECtHR, 24 July 2008) and, on appeal, (GC) 17 May 2010.

27 'We have witnessed periods of historical amnesia before. In the 1950s and 1960s, only a handful of memoirs and studies served to record and recall the Holocaust. The subject was virtually taboo, a consequence of the first and universally affirmed Stunde Null'. D Klein, 'The Fate of Holocaust Literature' in S Friedman (ed), Holocaust Literature (Westport, CT, Greenwood Press, 1993) xvi.

28 Council of Europe, Collected Edition of the 'Travaux Préparatoires' of the European Convention on Human Rights Vol I (The Hague, Martinus Nijhoff, 1975) 36 cited in Janis, Kay and Bradley, European Human Rights Law, n 6 above, 16.

29 E Bates, The Evolution of the European Convention on Human Rights (Oxford, Oxford University Press, 2010) 5, 6. Though this text explores, in depth, the origins and early years of the Convention system, it does not have any index entry under 'Holocaust'. 
This focus on creating a bulwark for the denizens of the 'free' West against the perceived threat from the East may account for, though not justify, the relative invisibility of the Holocaust for many decades at the ECtHR.

Generally, Holocaust related jurisprudence oscillates between the infamous (such as Eichmann, Ivan the Terrible), the misconceived or misunderstood (the Nuremberg trial so called had only limited Holocaust related focus) ${ }^{30}$ and the largely ignored or unknown (the Zyklon B case, a criminal trial in a British military court with no reasoned judgment). ${ }^{31}$ Much of this case-law is separated from the contemporary European legal space by distances of time and geography. The European legal order, which can be said, as a whole, to embrace both EU and Council of Europe institutions, has, apparently, been saved many of the challenges of institutionally confronting the collapse into savagery that was the Shoah. Yet, any enquiry into the meaning and limits of justice in Europe would acknowledge that the delivery of justice today needs to take account of lapses in justice in the past. This chapter, therefore, teases out the approach of the Strasbourg institutions towards the Shoah over the decades since their creation. The judgments and decisions looked at here are highlighted not only because of their relevance to an examination of justice in Europe but because of their intrinsic value in themselves in exposing something about the nature of European human rights approaches since 1959. The aim is to cast away the cobwebs from some significant but ignored case-law and to expose the details of some of those whose fate at Strasbourg was shaped by the Holocaust, its reality and its legacy. Dealing with the Shoah is an ongoing process, just as defining the meaning of justice in Europe is a process. In this volume, that latter process is approached largely from the inside, endogenously, from an EU perspective on the EU. This chapter steps back a little from 'Brussels' and examines the nature of European justice from an external perspective based on an assertion that justice has no conceptual borders; the EU and the Council of Europe are a collective experiment in the fashioning of a (just) Europe. As Allot asserts, 'Europe will be made by the Europe that Europe has made. Europe will be made by its own idea of what Europe could be'32 and that 'Europe' is both Brussels and Strasbourg.

The current academic and political preoccupation with the ECtHR has two focal points; reform of the Court system ${ }^{33}$ and the accession of the European Union to the ECHR. ${ }^{34}$ In other words, the focus is clearly on a modified future. The emphasis in this chapter faces towards the past rather than the future and examines the early decades of human rights adjudication from one specific perspective. The Holocaust constituted an extreme, extensive violation of what would, post facto, be classified as human rights yet Strasbourg proved not to be the locale for collective or

\footnotetext{
30 See W Schabas, Unimaginable Atrocities (Oxford, Oxford University Press, 2012); D Fraser, Law After Auschwitz (Durham, NC, Carolina Academic Press, 2005); and KJ Heller, The Nuremberg Military Tribunals and the Origins of International Criminal Law (Oxford, Oxford University Press, 2011).

31 Case No 9, The Zyklon B Case, The Trial of Bruno Tesch and Two Others Law Reports of Trials of War Criminals, United Nations War Crimes Commission, Vol 1, London, HMSO (1947).

32 P Allott, 'The European Community Is Not the True European Community' (1991) 100 Yale Law Journal 2485, 2490.

33 Greer, The European Convention on Human Rights, n 17 above.

34 See P Gragli, The Accession of the European Union to the European Convention on Human Rights (Oxford, Hart Publishing, 2013).
} 
high profile claims (which went to Jerusalem or Germany). Instead, the ECtHR records reveal decades of small scale, individual judgments and decisions, more often than not declared inadmissible, and which testify to the absence of any overt consciousness of the specificity of adjudicating Shoah related claims. This approach did, however, gradually begin to alter in the 1990s with Holocaust denial case-law and, more recently, with a heightened awareness of the Holocaust in freedom of expression case-law.

It could be said that the achievement of European human rights justice can be categorised as a type of fractal justice, the constantly shifting edges of which can never be fully measured. Nonetheless, some strata are identifiable. The evolution in Shoah related case-law in Strasbourg might be classified as follows:

1950s-80s Amnesia-no specific recognition of the uniqueness of the Holocaust despite direct confrontation with victims;

1990s Negationism - the emergence of a corpus of case-law on Holocaust denial; freedom of expression (Article 10 ECHR) cases involving Holocaust denial/ negation or revision; also post-1989 property related compensation claims; ${ }^{35}$

2010s Particularity — case law involving the use of Holocaust related language ${ }^{36}$ as well as continuing compensation claims. ${ }^{37}$ At the same time a new, overt, insistence that 'the Court is not a forum for the resolution of historical disputes' ${ }^{38}$

As institutions, the Council of Europe and the ECtHR provide Europe with a unique collective structure for remembrance, which is not replicated elsewhere in Europe. Every European state constantly creates and recreates its own individual history and memory; what Strasbourg offers, under the radar of both general appreciation of the ECtHR as a judicial body and outside the scope of general historical analysis, is a significant source of European memory mediated through a judicial lens. The HUDOC database is saturated with beguiling, complex and unexplored narratives, of the victims and the vulnerable of course, ${ }^{39}$ but also the victors. The Strasbourg judiciary has over 50 years' experience of exposure to the European past; that time has evidenced ebbs and flows but is always present, even more so today than in 1959. In that respect, it has been, effectively, the first and longest serving transitional justice court or, perhaps, an involuntary, unintended and unrecognised 'Truth Commission for Europe'. The literature on the ECtHR as a 'manager

\footnotetext{
35 Such as Slowik v Poland App No $30641 / 96$ (ECommHR Decision, 16 April 1998), an unsuccessful attempt to establish ownership of a planned parking lot in Warsaw which had previously been owned by two Jewish people killed in a concentration camp.

36 Such as PETA Deutschland $v$ Germany App No 43481/09 [2012] ECHR 1888 (ECtHR, 8 November 2012) (discussed below).

37 Such as Poznanski and Others $v$ Germany App No 25101/05 (ECtHR, 3 July 2007) (Jewish forced labourers at Auschwitz at the IG Farben factory based there). The applicants asserted that the maximum EUR 7,500 compensation for such slave labour was too low and, generally, that the compensation scheme was established to protect the interest of German industry and not the rights of forced labourers. The application was declared inadmissible.

38 As stated in LZ v Slovakia App No 27753/06 (ECtHR, 27 September 2011) (a Jewish applicant's attempt to stop a village street being named after Jozef Tiso, president of Slovakia during the Second World War), 'the Court is aware of the highly sensitive nature of the issues involved in the present case and its context ... However, it emphasises from the outset that it is not its task to settle possible points of debate among historians' (para 65).

39 See, further, András Sajó, 'Victimhood and Vulnerability As Sources of Justice' in this volume, 337.
} 
of memory' is sparse as most such work tends towards high profile case-law in Germany (Nuremberg, Frankfurt, etc) or Israel, ${ }^{40}$ but the ECtHR has in fact had to process the legacy of the Shoah and the Second World War more frequently than any other single judicial body. This has occurred in spite of the original conceptual failures highlighted above. The Katyn judgment ${ }^{41}$ is a recent and one of the most high profile of the 'history cases' in Strasbourg. Yet, it is low profile, unremembered decisions which constitute the main body of the ECtHR's claim to a status as an institution 'working through the past' ${ }^{42}$ An examination of widely scattered decisions and judgments from the perspective of the ECtHR encountering Europe's pasts exposes the extent to which 'thick descriptions of everyday life', ${ }^{43}$ tragic and non-tragic, are judged and, at one and the same time, the judges themselves judged too, especially from the perspective of the global conceptual purpose they might or could serve in this context.

There are several foundational questions relevant to an attempt to assess the ECtHR as a court of memory/history. First, who is or should be a 'victim' in the Strasbourg system? All Strasbourg applicants are formally classed as 'victims' (under Article $34 \mathrm{ECHR}$ ) but this is not inherently a neutral concept (an issue which is further explored in analysis of the National Socialist applications below). There is also the impenetrable question of what people choose to do with their memories and their narratives; if you have witnessed Kristallnacht, been incarcerated at several extermination/concentration camps and lost all your family at Auschwitz, ${ }^{44}$ what can human rights judges offer you? Why would you have faith in a legal system when another such system had so effectively enabled the atrocity? What purpose do human rights courts serve in relation to the uncompensatable? Beyond those questions is a consideration of how memory, mediated through the judicial route, represents and shapes the judges as well as the 'victims'. Furthermore, the governance or management of memory by and in judicial fora arguably runs counter to the very nature of memory itself; the very purpose of all judicial decisions is to close and finalise the legal issue in hand, to draw a line under the arguments raised, thus institutionalising or forcing a false forgetfulness rather than recognising the validity of a victim's memory and its endurance.

This overview of the work of the ECtHR has a specific interest in examining the Jewish presence in the Strasbourg jurisprudence. Do Jews go to court in Europe? ${ }^{45}$ Specifically, to what extent have European Jews benefited from the human rights court which was established as the extermination camps closed? There is widespread dissemination of knowledge about Jewish death within the European arena

40 See, eg, Fraser, Law After Auschwitz, n 30 above.

41 Janowiec and Others $v$ Russia App Nos 55508/07 and 29520/09 (ECtHR, 16 April 2012) and, on appeal, [2014] 58 EHRR 30 (ECtHR (GC), 21 October 2013).

$42 \mathrm{~T}$ Adorno, 'The Meaning of Working Through the Past' in T Adorno, Can One Live After Auschwitz? A Philosophical Reader, ed R Tiedemann (Stanford, CA, Stanford University Press, 2003$) 3$.

43 M Stolleis, 'The Spidery Monster: Inga Markovitz's Brilliant History of the GDR's Judiciary' (2007) 8 German Law Journal 195.

44 The facts of Xv Germany App No $627 / 59$ (ECommHR Decision, 14 December 1961) (Auschwitz survivor), discussed below.

45 See C Lyons, 'The Persistence of Memory' (2007) 32 European Law Review 563 for a similar question posed as regards the European Court of Justice. 
(museums, documentation centres, education programmes and the like) but far less awareness of Jewish life in Europe, now and then. ${ }^{46}$ The victims have become obscured by their killers in the institutional and judicial response to the Shoah. The high profile Einsatzgruppen military trials in 1947-48, the Eichmann trial in 1961, the series of extermination camp trials in Germany in the 1970s, the Demjanjuk (wrongly assumed to be Ivan the Terrible) trial in Jerusalem 1986, these have all easily entered the vocabulary and culture of atrocity to the detriment of those millions who were exterminated. Eichmann lives on (thanks to Arendt inter alia) ${ }^{47}$ but Walter Benjamin's brother, Raphael Lemkin's family, Jerry Springer's grandmothers and Stephen Fry's great grandparents ${ }^{48}$ are all eclipsed and forgotten. There is a superficial parallel in Strasbourg where many of the names of cases/ decisions involving Jews are rendered as $X$ versus (offering the protection but also the negation of anonymity) but those cases with convicted Nazi applicants from Germany are named and known. In general, it is fair to state that much judicial and academic space devoted to the consideration of the consequences of National Socialism has revolved around its adherents and not its victims; we readily debate the concept of 'banality of evil' in the seminar room but rarely analyse the detail of, for example, the Einsatzgruppen trials or of how Treblinka functioned.

The chapter structure adopts the conceit of the concept of stolpersteine $e^{49}$ for an identification of significant markers in the pathway towards the ECtHR's recognition of Shoah specificity within the canon of European human rights. The idea behind the stolperstein is to symbolise the return of the lost person to their neighbourhood and community. The focus on Holocaust case-law here suggests that Strasbourg case-law is, too, a means of conveying individual, ignored, Shoah victims back to the European legal community. More generally, ECtHR adjudication is a means of bringing (back) the Holocaust into the realm of European justice. One of the most recent stolperstein, from November 2012, is the minority opinion in PETA, ${ }^{50}$ which forcefully argues for the European wide relevance of the Holocaust and its legacy. Fifty years before, the Strasbourg human rights system and its institutions were relatively oblivious to those few applicants who 'stumbled' before them and making no case for Shoah relevance in the formation of a new human rights system. This chapter outlines the steps on that passage from a dearth of acknowledgement of the relevance of the Holocaust towards a more recent intimation that the uniqueness of the Shoah may necessitate a distinct-and European-interpretation of Convention rights.

\footnotetext{
${ }^{46}$ But see the important, recent series of reports from the EU's Fundamental Rights Agency showing a rise in anti-Semitism across Europe, 'Discrimination and Hate Crime Against Jews in EU Member States: Experiences and Perceptions of Antisemitism' (November 2013), www.fra.europa.eu/en/ publication/2013/discrimination-and-hate-crime-against-jews-eu-member-states-experiences-and.

47 H Arendt, Eichmann in Jerusalem: A Report on the Banality of Evil (London, Penguin Books, 2006).

48 All of whom were killed in Nazi-occupied Europe.

49 A project devised and implemented by German artist Gunter Demnig which involves placing small brass plaques - to be 'stumbled' over-in the pavements outside the last known addresses of those killed in the Holocaust. See www.stolpersteine.eu/en/.

50 PETA Deutschland $v$ Germany App No 43481/09 [2012] ECHR 1888 (ECtHR, 8 November 2012), Concurring Opinion of Judges Zupančič and Spielmann.
} 


\section{THE LEGEND OF THE JUST MEN}

Justice in Strasbourg is primarily the responsibility of the judges of the Court. Now, and in the past, are these judges who can give/write judgments equal to the events they judge, ${ }^{51}$ specifically in the context of contentious claims arising from or related to Europe's past? Have victims always been served by 'just men'?52 Relevant also to a questioning of the who and how of human rights justice in Strasbourg is a recall of the complex juxtaposition of different layers of adjudication in Europe; take, for example, the early 1960s. Seven men in Luxembourg are fashioning, from Dutch tax law and Italian electricity prices, the constitutional foundations of the EU in Van Gend \& $\operatorname{Loos}^{53}$ and Costa/ENEL; ${ }^{54}$ the ECtHR, meantime, in de Becker, ${ }^{55}$ is adjudicating the claims of a convicted Second World War collaborator; the Commission in Strasbourg is declaring inadmissible the claim of an Auschwitz survivor $;^{56}$ in Düsseldorf, criminal judges are dealing with the killing of 900,000 people in one year (the Treblinka trials). ${ }^{57}$ In other words, meting out justice, or assessing the quality or extent of that justice, in post-war 'Europe', broadly defined, is not quantifiable on any simplistic level.

There is also the issue of distance from the past, from the events of the specific claim, in Strasbourg case-law dealing with the Holocaust. In the 1960s, during the early phase of Shoah case-law, the judges and members of the European Commission had direct, lived experience of the facts before them. Today, the facts will inevitably have become 'history' for the judges (if not always necessarily for the applicants). How might this distance/proximity issue have altered the nature of human rights judging? Barthes reminds us that 'History is hysterical: it is constituted only if we consider it, only if we look at it and in order to look at it, we must be excluded from it. Michelet was able to write virtually nothing about his own time' ${ }^{58}$ The process of dealing with the past, a process which has acquired a (too convenient?) German appellation, Vergangenheitsbewältigung is, intrinsically, a delayed process; the past cannot be dealt with as such until it has in fact become the 'past'. This may account for the increased recognition of the Holocaust in the

51 Taussig recalls for us how Nietzsche pleaded 'in vain for historians who can write histories equal to the events they relate', in M Taussig, Walter Benjamin's Grave (Chicago, IL, University of Chicago Press, 2006) 7.

52 This is borrowed from A Schwarz-Bart, The Last of the Just (London, Penguin, 1984) 10, where the author refers to 'the Jewish tradition of the Lamed-waf. According to this tradition, the world reposes upon thirty six Just Men, the Lamed-Waf, indistinguishable from simple mortals; often, they do not recognise themselves. The Lamed-waf are the hearts of the world multiplied, into which all our griefs are poured, as into one receptacle'.

53 Case 26/62 NV Algemene Transport- en Expeditie Onderneming van Gend \& Loos v Nederlandse administratie der belastingen [1963] ECR (Special English Edition) 1.

54 Case 6/64 Costa $v$ ENEL [1964] ECR (Special English Edition) 585.

55 De Becker v Belgium App 214/56 Series A No 4 (ECtHR, 27 March 1962).

56 X $v$ Germany App No $627 / 59$ (ECommHR Decision, 14 December 1961) (Auschwitz survivor).

57 See www.holocaustresearchproject.org/trials/treblinkatrial.html.

58 R Barthes, Camera Lucida (London, Vintage, 1993) 65. 
last decade or so; the Strasbourg judicial community needed to be 'excluded' (à la Barthes) from the Shoah in order to properly confront it. ${ }^{59}$

Adopting an openness to the legacies of the Nazi era does not have to mean a wallowing in guilt or shame but a recognition of the fact that, as Joerges points out, 'this legacy is not merely precious, it is also precarious' ${ }^{60}$ The management of Europe's past $(\mathrm{s})^{61}$ is not a duty falling to one or two Member States but is a generalised, European responsibility. One unpredictable outcome of a lengthy reflection on the nature of the legacy is that questions of German accountability have been brought into a European context. ${ }^{62}$ This comes to light in PETA (discussed below) where the German Government submissions are unusually apologetic in nature. ${ }^{63}$

\section{THE COURT OF GRIEF}

And so it was for millions who from Luftmensch became Luft. ${ }^{64}$

The legacy of the Holocaust and the Second World War is an enduring (and, paradoxically, increasing) one of loss and grief. How do victims express this grief in Strasbourg? ${ }^{65}$ Is it a fallacy that courts are non-emotional, non-sentimental spaces? Even if the text (the Convention) restricts and limits (because of the original sin as discussed above), does this, de facto, curtail the victim's expression of loss? Theodor Adorno suggests that, after Auschwitz, the temporal core is to be found

59 There is perverse example of this in a 2006 judgment of the Austrian Supreme Court referred to in PETA; the contested PETA posters with Holocaust victims and animals juxtaposed, which were the subject of litigation in Germany, Austria and Strasbourg, were deemed, in Austria, to aid the process of dealing with the past as they 'had the positive effect of rekindling the memory of the national-socialist genocide. The concentration camp pictures documented the historic truth and recalled unfathomable crimes, which could be seen as a positive contribution to the process of dealing with the past (Vergangenheitsaufarbeitung)'. PETA Deutschland v Germany App No 43481/09 [2012] ECHR 1888 (ECtHR, 8 November 2012), para 23, referring to Judgment No 6 Ob 321/04f (Austrian Supreme Court of Justice, 12 October 2006).

${ }^{60}$ C Joerges, 'Introduction to the Special Issue: Confronting Memories: European "Bitter Experiences" and the Constitutionalization Process: Constructing Europe in the Shadow of Its Pasts' (2005) 6 German Law Journal Special Issue, ed C Joerges and B Blokker 245, 246.

61 See Christian Joerges on this: 'Was bedeutet: Aufarbeitung der Vergangenheit is the title of a famous essay by Theodor W Adorno, written in 1959, in which he took issue with what the Germans have coined Vergangenheitsbewältigung: How can Germans ever "come to terms" with AuschwitzVergangenheitsbewältigung is definitely and rightfully resistant against/to translation exercises.' ibid 248.

62 Exchanges with Christian Joerges, August 2007.

63 'The [German] Government considered that they should be granted a wide margin of appreciation allowing a generous definition of the group of affected persons. This applied, in particular, in light of Germany's history, which meant that it was hardly conceivable that a German court would reach a similar conclusion as the Austrian Supreme Court. Given its historical responsibility, it was Germany's duty to ensure that violations of personality rights could be claimed in connection with the Holocaust. The individuals depicted on the photographs were, almost without exception, unable to do this themselves.' PETA Deutschland v Germany App No 43481/09 [2012] ECHR 1888 (ECtHR, 8 November 2012), para 36.

64 Schwarz-Bart, The Last of the Just, n 52 above.

65 Grief: 'This word may be understood in French as: damage, blame, prejudice, injustice or injury but also ... complaint, the call for punishment ... In English ... grievance also expresses the subject of the complaint, injustice, conflict, a wrong that must be righted, a violence to be repaired.' J Derrida, The Politics of Friendship (London, Verso, 1997) ix. 
in the screams of the victims. ${ }^{66}$ Who, then, 'screams' (loudest) in Strasbourg, the perpetrator or the victim? From some of the case-law detailed below, one implication is that victims' screams were not very well heard in the early years of European human rights.

Pierre Nora explores the differences between memory and history. ${ }^{67}$ It is an analysis which helps us to appreciate the dichotomy between a victim/applicant with memories and the human rights judge who has to respond to the latter. A judicial setting is the embodiment of Nora's memory/history duality and disjunction. Memory: origins in primitive/peasant rituals of passing on, in oral tradition; secretive; organic; intimate. History: formal; impenetrable; preserve of elites; a reconstitution of what is; besieges and petrifies memory. Nora's perspective would suggest that a (human rights) court can only deal with history but will never be an apt lieu for memory reception because it formalises and renders public that which is inherently private.

Hannah Arendt's reflection on the role of the judges at the Eichmann trial resonates in this context also: 'The purpose of a trial is to render justice, and nothing else; even the noblest of ulterior purposes ... can only detract from the law's main business: to weigh the charges brought against the accused, to render judgment and to mete out due punishment'. ${ }^{68}$ There are arguments which can be made in relation to this statement per se but even more so in the context of human rights adjudication.

Finally, is the function of the (European) human rights chamber limited to doing justice in the case at hand or can a more constitutionally significant role (placing the claim in a larger, historically relevant context) be conceived of for a regional human rights court? ${ }^{69}$ This was not the case in the early era of Strasbourg human rights jurisprudence but more recent case-law elevates the Holocaust from an individual compensation claim case level to a higher level as independent factor affecting the interpretation of specific Convention provisions. András Sajó also discusses in his chapter 'how the judiciary handles past collective injustice against groups of citizens can be of foundational constitutional importance'. ${ }^{70}$

At the Einsatzgruppen trials in 1947 Judge Musmanno said in his judgment 'these narratives go beyond the frontiers of human cruelty and savagery'. ${ }^{71}$ In the decades since then, detailed knowledge about that savagery has become widely available. And, as well as those killing squad military trials in 1947, there have been separate domestic criminal trials in Germany in relation to Auschwitz, Bełżec, Sobibor and Treblinka. ${ }^{72}$ Furthermore, the Federal Republic of Germany operated a long-term

66 Adorno, 'The Meaning of Working Through the Past', n 42 above, xviii.

67 P Nora, 'Between Memory and History: Les Lieux de Mémoire' (1989) 26 Representations 7.

68 Arendt, Eichmann in Jerusalem, n 47 above, 253 cited in Schabas, Unimaginable Atrocities, n 30 above, 157 where 'History, International Justice and Truth' are discussed at ch 6.

69 Williams, 'Burying, Not Praising', n 18 above; and S Douglas-Scott, 'Europe's Constitutional Mosaic: Human Rights in the European Legal Space-Utopia, Dystopia, Monotopia or Polytopia?' in N Walker, J Shaw and S Tierney (eds), Europe's Constitutional Mosaic (Oxford, Hart Publishing, 2012).

70 See Sajó, 'Victimhood and Vulnerability As Sources of Justice' in this volume, 337, at 339.

71 US $v$ Otto Oblendorf et al (Einsatzgruppen) United States Military Tribunals at Nuremberg (1948) Case No 9, TWC Vol IV 1.

72 See generally Schabas, Unimaginable Atrocities, n 30 above; and Fraser, Law After Auschwitz, n 30 above. 
restitution and compensation scheme for victims of National Socialism. ${ }^{73}$ Yet, military tribunals, criminal courts and monetary bureaucracy_it might be asked, is that it? It is notable that the efficiency and smooth running of the institutionalised killing system should be matched with a convenient and minimally disruptive judicial and administrative response. David Fraser's comprehensive examination of post-Shoah adjudication takes in (criminal) courts in France, the US, the UK, Canada and Australia. ${ }^{74}$ It does not, tellingly, have a chapter on the European Court of Human Rights. Shoah cases are apparently everywhere save Strasbourg. Judges as far away Canberra ${ }^{75}$ 'work through the past', deal with the consequences of an all too European period of barbarity yet the human rights judges of Europe have made a less than significant contribution to the judicial appreciation of the Holocaust. Partly this is due to the original sin as discussed, the fundamental failure to include crimes against humanity and a concept of genocide in the ECHR; partly this is due to the inability of the Commission and the Court to determine which types of applicants take the journey to eastern France; partly it is due to the Commission/Court response when a Shoah related case does reach its doors. Could all these factors unintentionally coalescing be said to be an example of Agamben's ethical aporia of Auschwitz, of the blindness of law after Auschwitz? ${ }^{76}$

\section{NOMEN EST NUMEN}

It is more arduous to honour the memory of the nameless than that of the renowned. Historical construction is devoted to the memory of the nameless. ${ }^{77}$

When viewing a global picture of case law in Strasbourg, the punctum ${ }^{78}$ is the case law (or more precisely the lack of it) relating to destruction of European Jewry. This is the detail that 'pricks' when the Strasbourg system is viewed from behind the veil of the Convention text so to speak. One of the decisions which embodies that punctum is the case of $X v$ Germany, ${ }^{79}$ a European Commission on Human Rights (ECommHR) decision of $1961 .{ }^{80}$

\footnotetext{
73 Now 'rebranded' as the Remembrance, Responsibility and Future Foundation, www.stiftung-evz. de/eng/home.htm.

74 Fraser, Law After Auschwitz, n 30 above.

75 Minister for Home Affairs of the Commonwealth v Zentai [2012] HCA 28 (15 August 2012).

76 G Agamben, Remnants of Auschwitz (London, Zone Books, 1999), discussed at length in Fraser, Law After Auschwitz, n 30 above, ch 3.

77 Walter Benjamin, Inscription on artwork at Port Bou cemetery, Spain where Benjamin died.

78 Barthes, Camera Lucida, n 58 above, 27 on the concepts of Studium (general appreciation (of a photograph)) and Punctum: 'The second element will break (or punctuate) the stadium, this element which arises from a scene, shoots out if it like an arrow and pierces me. A Latin word exists to designate this wound, this prick. A photograph's punctum is that accident which pricks me (but also bruises me, is poignant to me)'; 43: 'The punctum is a detail, a partial object'; 45: 'There is another, (less Proustian) expansion of the punctum: when, paradoxically, while remaining a detail, it fills the whole picture'; 51: 'What I can name, cannot really prick me. The incapacity to name is a good symptom of disturbance.'

79 X v Germany App No $627 / 59$ (ECommHR Decision, 14 December 1961) (Auschwitz survivor).

80 The European Commission of Human Rights, which operated from 1954 until 1998 when it was abolished, served as a filtering system for the Court of Human Rights, deciding on the admissibility or otherwise of applications from individuals, who did not have direct access to the Court itself. Many of the early era applications in Holocaust related cases during the Amnesia phase failed to pass the admissibility scrutiny of the Commission.
} 


\section{A. Stolperstein 1-X (The Auschwitz Survivor)}

X survived Auschwitz; his location at this camp can be surmised only from the Commission Admissibility Decision as, like the applicant himself, it is not named and is called camp ' $\mathrm{C}$ ' only in the Decision. ${ }^{81} \mathrm{He}$ witnessed his whole family, all his relatives taken to the gas chamber there. He had previously been sent to an unnamed Ghetto and was at several other concentration camps before being liberated by the Russians in 1945. This trauma began on 9 November 1938, Kristallnacht, ${ }^{82}$ when his father's well-established printing firm was destroyed. After the war, X reopened the family firm in East Germany but relocated the firm to West Germany after his escape from the German Democratic Republic.

$\mathrm{X}$ brings this narrative, which encapsulates almost the whole spectrum of Nazi Final Solution measures (pogrom, ghettoisation, extermination) to seek justice at Strasbourg. He may be nameless but he is the living proof, writ judicial, of the history of National Socialism and its legacy. He sees the broken glass of Kristallnacht, was moved to a Ghetto then finally, the ultimate last stop, Auschwitz. What differentiates X from millions of others who shared this ordeal, apart from his miraculous survival, is his journey to the ECtHR, bringing this explicit narrative to the heart of the new Europe. X's very witnessing of the smoke of Auschwitz and a human rights judge within 15 years of each other captures the seismic transformations represented by the Strasbourg system. Did even the prospect of human rights seem like a parallel universe to somebody who had been deprived of his very humanity? At the very least, he provides a form of proof, an undeniable certainty that all this happened, evidence which bypasses the historian, showing the Shoah without mediation, the facts established without method. ${ }^{83}$ Not that the Commissioners would not have known this in a general sense as, for them, in 1961, X's story is not 'history' but merely the factual back story of an (ultimately unsuccessful) victim/applicant and is related and recorded as such. The Commission declares X's claim to be inadmissible due to the failure to exhaust domestic remedies in West Germany. However, there is yet another layer of complexity in X's application; his claim is partly based on the fact that in a criminal trial against him in the Federal Republic, the judges were former members of the Nazi party and one of the witnesses for the prosecution was responsible for the arrest and subsequent extermination of his parents in Auschwitz. First, so much for so called de-Nazification. But, how can we appraise a human right forum, which compels an Auschwitz survivor to pursue his claim in a judicial system populated by former persecutors?

\footnotetext{
81 Nomem est numen, to name is to know, but not in the case of this applicant who, previously only a number, is now an anonymous applicant.

82 '[T] he universally adopted, almost good-natured expression Kristallnacht, designating the pogrom of November 1938, attests to this inclination [to use euphemistic circumlocutions in the reminiscences of deportations and mass murder]. A very great number claim not to have known of the events at the time, although Jews disappeared everywhere and although it is hardly believable that those who experienced what happened in the East constantly kept silent.' Adorno, 'The Meaning of Working Through the Past', n 42 above, 4 .

83 See Barthes, Camera Lucida, n 58 above, 81, in this vein, discussing photographs of slaves and former slaves.
} 
$\mathrm{X}$ is a rare Strasbourg applicant in many respects; very few Jews and no Jewish women or children ${ }^{84}$ appear in the early decades of European human rights law. The lack of an appropriate conceptual underpinning of the ECHR is therefore matched by a lack of applicants who might otherwise have exposed the new human rights regime to that which it was largely ignoring. How many European Jews have had the opportunity to formally 'bear witness' to their experiences in a judicial setting, let alone a human rights one? X's multilayered life is of even more interest to legal analysis when his specific complaint is considered: he alleges continuing Nazi bias in the judges he has had to face in post-war West Germany. Sentiment aside, though is difficult not to convey compassion for this persistent victim, this case contains prophetic material which will not reach the academic arena for many decades later. X did not receive justice in Strasbourg, nor presumably in West Germany thereafter given the evidence of continuing anti-Semitism and victimisation. The 1961 Commission was, no doubt, performing a mere administrative task in assessing, formally, the exhaustion of domestic remedies by X. But it seems necessary, at least at this distance, to question how human rights lawyers would have sent an Auschwitz survivor back to West Germany to be judged by former Nazis.

\section{THE WRONG KIND OF JUSTICE?}

In a book considering the nature of European justice it is worth pondering if justice should serve only the good? Is there an automatic dearth or deficit of justice if the (money) banks are propped up while the queues at the food banks lengthen daily? Is justice to be judged so when it serves only the just? Do the angels get all the (best) tunes in a just system? While this question may be answered in a different way in economic terms, a human rights court delivers justice to those with both clean and dirty hands. ${ }^{85}$ Thus it was that Strasbourg institutions have had direct contact with several former National Socialists over the years, such as in the applications and cases of $X(1961),{ }^{86}$ Ilse Koch (1962), ${ }^{87}$ Heinz Jentzsch (1970), 88 Ilse Hess (1975), ${ }^{89}$ and Anthony Sawoniuk (2001). ${ }^{90}$ Not all of the stolpersteine, the markers of remembrance put forward here, are positive; the Strasbourg institutions can be successfully mined for 'the banality of evil' just as much for suffering and injustice.

\footnotetext{
84 At least 1 million Jewish children and 1.5 million children altogether are estimated to have been murdered taking the 'journey to Pichipoi' (a name invented by Jewish children awaiting deportation in the Drancy prison/holding camp in France).

85 Recalling the equity maxim that, (s)he who comes to equity must come with clean hands.

86 Xv Germany App No 920/60 (ECommHR Decision, 19 December 1961). X, a senior SS officer, was involved in the mass execution of Jews at an unidentified location in the Soviet Union during 1942-43. This Decision was issued five days after the Commission ruled in the X $v$ Germany App No 627/59 (ECommHR Decision, 14 December 1961)(Auschwitz survivor).

87 Ilse Koch v Germany App No 1270/61 (ECommHR Decision, 8 March 1962).

88 Heinz Jentzsch $v$ Germany App No 2604/65 (ECommHR Decision, 6 October 1970).

89 Ilse Hess $v$ United Kingdom App No 6231/73 2 DR 72 (ECommHR Decision, 28 May 1975).

90 Anthony Sawoniuk v United Kingdom App No 63716/00 (ECtHR, Admissibility Decision, 29 May 2001).
} 


\section{B. Stolperstein 2-X (The SS Officer)}

$\mathrm{X}$ was a senior SS officer who was involved in the mass extermination of Jews at an unidentified location during 1942-43. He was imprisoned in West Germany after the Second World War but was claiming compensation for being wrongly detained. Here is part of his claim which merits quotation at length:

In 1961 the District Court of C decided again that the Applicant [X] could not be released as there was a risk that he might flee the country, and it prolonged his detention until 1962. He is claiming damages of 500,000 DM to compensate him for loss of honour, loss of income, for the distress caused to his family and for the nervous depression from which he suffers as a result of his detention. He states that he is merely a scapegoat who exterminated Jews under compulsion and that the persons responsible for the atrocities of the third Reich are the Western democracies and the politicians of the Weimar Republic who, by their stupidity, lack of moral integrity and lack of courage, paved the way for Hitler's assumption of power. [Emphasis added.] ${ }^{91}$

Whatever the ultimate result in this case, the very existence of those words in the ECtHR records are a testament to the nature of Holocaust appreciation in the decades after 1945. Furthermore, this mass murderer's words disturb as they draw attention to the role of the Allies in not attempting to prevent the savagery in the first place. X's application for compensation for violation of Article 5 ECHR (delay in trial proceedings) was deemed inadmissible. However, in a manner which was not followed in the $X$ (Auschwitz survivor) application, the Commission here places this SS officer's claim into a wider context, the inadmissibility being based on the justification of the need for West Germany to have the time to gather evidence for a large trial. ${ }^{92}$

\section{Stolperstein 3-Heinz Jentzsch (SS Guard)}

The Jentzsch decision is remarkable in the first instance as the (very lengthy) ${ }^{93}$ ECommHR decision considers war crimes and crimes against humanity (in the context of whether there are special problems of arrest and detention arising in the prosecution of war crimes and crimes against humanity) and it is clearly an application which much exercised the Commission members; there are three individual Opinions (two dissenting). ${ }^{94}$

Heinz Jentzsch was an SS guard at Mauthausen/Gusen concentration camp and was detained pre-trial in Germany from 1961 until 1967. One of the methods of

\footnotetext{
91 X $v$ Germany App No 920/60 (ECommHR Decision, 19 December 1961).

92 'Whereas the crimes imputed to the Applicant formed merely a part of the large-scale crimes committed by the SS in the German-controlled territories in Eastern Europe in 1941-45; whereas, consequently, the participation of the Applicant in the mass exterminations at B. in 1942-43 cannot be properly assessed in isolation but must be seen in its full perspective, which can only be obtained by a trial involving all those who participated in the crimes concerned.' X $v$ Germany App No 920/60 (ECommHR Decision, 19 December 1961).

93 Sixty-seven pages with a few hundred pages of appendices; X $v$ Germany App No 627/59 (ECommHR Decision, 14 December 1961) (Auschwitz survivor), is only four pages long.

94 Heinz Jentzsch $v$ Germany App No 2604/65 (ECommHR Decision, 6 October 1970).
} 
killing used in Gusen was the so-called 'death bath', forcing ill and/or old prisoners to stand under ice cold showers while being beaten (by Jentzsch and others) to death. He was convicted in 1968 of murdering at least 20 people and sentenced to life imprisonment. He was granted free legal aid to support his application to the ECtHR for compensation for breach of Article 5 (delayed period of detention before trial).

The West German Government argued that in cases of war crimes and crimes against humanity, courts and public prosecutors were in a particularly difficult position which could not be measured by the same standards as ordinary criminal cases. ${ }^{95}$ In terms of this chapter's support of Williams's assertion of the lack of original conceptual underpinning of the Convention, it is positive to note that the Commission in Jentzsch directly addresses the issue of potential lack of jurisdiction and non-retroactivity. It finds that Article 7(2) ECHR ${ }^{96}$ covers war crimes and crimes against humanity. A complication arises because West Germany has entered a reservation as regards Article 7(2) so that it will not be applied except in accordance with the principles of the Article 103(2) of the Grundgesetz such that no act can be punished unless it was a punishable offence before it was committed. Thus, 23 years before Brunner ${ }^{97}$ a 'supranational' judicial entity has a constitutional conundrum arising from National Socialism's long reach. This is resolved in this instance by the Commission's categorisation of Jentzsch's case as based on Article 5(3) and a finding that he is entitled to the protection of that provision even though convicted of crimes against humanity. Justice for the dirty handed.

\section{NO SHOAH?}

The Strasbourg institutions may have demonstrated a generalised reticence to engage directly with the significance of the Holocaust in the Amnesia phase during the 1950s to the 1980s. As we saw above, claims during that period were, largely, individual, compensation type claims. The genres of Shoah case-law, however, segued from the compensation category to freedom of expression cases (Article 10 ECHR) in the 1990s. No longer was the ECtHR faced with individuals with direct, personal experience of a death camp (as a victim or a guard) but instead with writers, journalists and others who claimed that those camps either did not exist or did not operate as death camps. These judgments generated a whole new category of 'hate speech' case-law centered on the denial of the Holocaust. This phase of Shoah jurisprudence, Negationism, represents a significant shift in several respects; the focus is no longer on individual Holocaust related claims per se but rather a consideration of the freedom of expression rights of those who contest it. The judgments necessarily move away from a direct confrontation of Holocaust suffering to a generalised, scientific level of appreciation of the Holocaust. Yet, despite the distance in terms of applicants and substance, the ECtHR is, perversely, by this era dealing with the Shoah in a more extensive way than it has done since its establishment. The

\footnotetext{
${ }_{95}$ Heinz Jentzsch $v$ Germany App No 2604/65 (ECommHR Decision, 6 October 1970), para 7.

96 'This Article shall not prejudice the trial and punishment of any person for any act or omission which, at the time when it was committed, was criminal according to the general principles of law recognized by civilized nations'.

97 BVerfGE 89, 155, 2 BvR 2134/92 and $2159 / 92$ (12 October 1993).
} 
outcome of a range of cases in this context is the establishment of a precedent that the negation or revision of the Holocaust will engender a specific interpretation of Articles 10 and 17 ECHR. ${ }^{98}$ As the Grand Chamber stated in Lehideux and Isorni, '[the disputed publication] does not belong to the category of clearly established historical facts - such as the Holocaust - whose negation or revision would be removed from the protection of Article 10 by Article 17'.99 In essence, after Lebideux, it is clearly established that the European human rights system recognises a special level of protection for the facts of the Holocaust. This has been confirmed by the Court in Witzsch ${ }^{100}$ and Garaudy. ${ }^{101}$

\section{VII. 'THE HOLOCAUST ON YOUR PLATE'}

We enter a third phase (Particularity) of Holocaust jurisprudence with the recent judgments in Hoffer and Annen ${ }^{102}$ and, especially, PETA. ${ }^{103}$ Particularity in this context refers to the evolution and maturation of the Strasbourg judicial approach to a point where the unique nature of the Holocaust in Europe's past is recognised above and beyond mere denial scenarios.

\section{Stolperstein 4-PETA}

In 2004, the animal rights organisation, PETA (People for the Ethical Treatment of Animals) planned an advertising campaign in Germany to be called 'The Holocaust on your plate'. This involved posters with death camp photographs on one side opposite images of animals. ${ }^{104}$ The intended campaign was challenged by

98 See, interalia, Marais v France App No 31159/96 86 DR 184 (ECommHR Decision, 24 June 1996); Honsikv Austria App No 25062/94 83 DR 77 (ECommHR Decision, 18 October 1995); Lehideux and Isorni v France App No 24662/94 [1998] ECHR 90 [2000] 30 EHRR 665 (ECtHR (GC), 23 September 1998).

99 Lehideux and Isorni $v$ France App No 24662/94 [1998] ECHR 90 [2000] 30 EHRR 665 (ECtHR (GC), 23 September 1998), para 46.

100 'Against this background, the Court finds that the public interest in the prevention of crime and disorder due to disparaging statements regarding the Holocaust, and the requirements of protecting the interests of the victims of the nazi regime, outweigh, in a democratic society the applicant's freedom to impart views denying the existence of gas chambers and mass murder therein.' Witzsch v Germany App No 41448/98 (ECtHR, Admissibility Decision, 20 April 1999), para 1.

101 Garaudy v France App 65831/01 [2003] ECHR IX (ECtHR, Admissibility Decision, 7 July 2003).

102 Hoffer and Annen $v$ Germany App Nos 397/07 and 2322/07 [2011] ECHR 46 (ECtHR, 13 January 2011).

103 PETA Deutschland v Germany App No 43481/09 [2012] ECHR 1888 (ECtHR, 8 November 2012).

104 'The intended campaign, which had been carried out in a similar way in the United States of America, consisted of a number of posters, each of which bore a photograph of concentration camp inmates along with a picture of animals kept in mass stocks, accompanied by a short text. One of the posters showed a photograph of emaciated, naked concentration camp inmates alongside a photograph of starving cattle under the heading "walking skeletons". Other posters showed a photograph of piled up human dead bodies alongside a photograph of a pile of slaughtered pigs under the heading "final humiliation" and of rows of inmates lying on stock beds alongside rows of chicken in laying batteries under the heading "if animals are concerned, everybody becomes a Nazi". Another poster depicting a starving, naked male inmate alongside a starving cattle bore the title "The Holocaust on your plate" and the text "Between 1938 and 1945, 12 million human beings were killed in the Holocaust. As many animals are killed every hour in Europe for the purpose of human consumption". PETA Deutschland $v$ Germany App No 43481/09 [2012] ECHR 1888 (ECtHR, 8 November 2012), para 7. 
three Holocaust survivors who successfully sought an injunction, though the case spent five years in the German judicial system. PETA then pleaded Article 10 in Strasbourg where, ultimately, no breach was found.

PETA should be given to every first year law student to watch them unravel the labyrinth of human rights versus animal welfare, cultural relativism, historical significance, multilayered adjudication and human rights universality. PETA is not an uncomplicated decision; the majority judgment was followed by an, apparently, concurring Opinion from the President of the Court, Judge Spielmann and the Slovenian Judge Zupančič. The latter take issue, in forceful and persuasive terms, with what might be called the exceptionalism element of the judgment. That is, German exceptionalism to the extent that the judgment states that the offensive advertising campaign was unacceptable and not permitted by Article 10 but only in Germany. ${ }^{105}$ This relativisation of freedom of expression is condemned in the minority Opinion, according to which, the debasement of death camp victims by comparing them to hens and pigs should be unacceptable from Azerbaijan to Iceland and not just in Germany. In 1961, the fact of ex-Nazi judges judging an Auschwitz survivor is not a Strasbourg concern but deemed to be a domestic German issue. By 2012, advertising which is offensive to Holocaust victims is very much a matter for Strasbourg adjudication. One important reading of this minority Opinion, if not the judgment, in PETA, is the Europeanisation of the legacy of the Holocaust, as brought about by Strasbourg human rights.

\section{THE ORIGIN IS THE GOAL}

Adorno thought it inconceivable that 'life would continue normally' after the Shoah and a sense of shame prevented him writing eloquently about Auschwitz. ${ }^{106}$ In 1959, at the same time as the first judgments issued from Strasbourg, he discerned in Germany a rejection of the past that would cheat the murder victims of their right to be remembered, there was 'an empty and cold forgetting': 107 'Suffering needed to be enabled to speak. Law and philosophy today must be one in which suffering in death camps is present in every one of its sentences'. 108

How to apply this to the history of jurisprudence at Strasbourg? This chapter began with arguments about the original lack of philosophy and purpose and closes with an acknowledgement that, if 'the origin is the goal', ${ }^{109}$ the Strasbourg institutions have gradually, eventually approached that goal/origin. It might still be said

\footnotetext{
105 'The Court considers that the facts of this case cannot be detached from the historical and social context in which the expression of opinion takes place. It observes that a reference to the Holocaust must also be seen in the specific context of the German past and respects the Government's stance that they deem themselves under a special obligation towards the Jews living in Germany ... In the light of this, the Court considers that the domestic courts gave relevant and sufficient reasons for granting the civil injunction against the publication of the posters. This is not called into question by the fact that courts in other jurisdictions might address similar issues in a different way'. PETA Deutschland v Germany App No 43481/09 [2012] ECHR 1888 (ECtHR, 8 November 2012), para 49.

106 Adorno, 'The Meaning of Working Through the Past', n 42 above, xi.

107 ibid, xii.

108 ibid.

109 Attributed to Karl Kraus in P Szondi, 'Hope in the Past: On Walter Benjamin' in W Benjamin, Berlin Childhood Around 1900 (Harvard, Harvard University Press, 2006) 29.
} 
of cases such as $X$ (Auschwitz survivor) above that 'it's as good as if it never happened; the murdered are to be cheated out of the single remaining thing that our powerlessness can offer them: remembrance'. ${ }^{110}$ But, taking a route via Holocaust denial, the Strasbourg human rights system has reached a point where the 'origin', the ignored shadow against with the ECHR was drafted, has now acquired a status in the case-law which begins to accord mass extermination and suffering value and recognition in itself.

\section{ENDING}

In Europe, there are positions to defend. ${ }^{111}$

It was reported in a Dutch newspaper in February 1942 that potatoes were to be transported to Berlin in heated railway wagons so as to prevent frost damage. ${ }^{112}$ The human occupants of German railway wagons at the same time were not so fortunate. In this small insight into a united Europe under German control in 1942, there are echoes of a united Europe of the future. Might it be said that European integration is still overly concerned with potatoes, goods, property, standardisation and health and safety rather than with humanity? And, moreover, that this preoccupation contributes to a hindering of the achievement of justice at the European level? ${ }^{113}$

I suggest at the close of this chapter that, despite the lack of appropriate conceptual underpinning or a founding philosophy in Strasbourg, the current and more recent jurisprudence evidences a human rights system formulating and supplying a kind of justice which now recognises the 'origin' and is beginning to be that which it was not allowed to be in 1950. The Convention acquis ${ }^{114}$ is enriched and enhanced ultimately rather than devalued by unearthing the 'sins' of the past. In exposing the institutional approaches to Europe's pasts it can be seen that the ECHR is, and needs to be, more than a self-serving collective insurance policy (against totalitarianism). ${ }^{115}$ 'The past will have been worked through only when the causes of what happened then have been eliminated. Only because the causes continue to exist does the captivating spell of the past remain to this day unbroken'. ${ }^{116}$

And praised be Auschwitz. So be it. Maidenek. The Eternal. Treblinka. And praised be Buchenwald. So be it. Mauthausen. The Eternal. Belzec. And praised be Sobibor. So be it. Chelmno. The Eternal. Ponary. And praised be Theresienstadt. So be it. Warsaw. The Eternal. Wilno. And praised be Skarzysko. So be it. Bergen Belsen. The Eternal. Janow. And praised be Dora. So be it. Nuengamme. The Eternal. Pustkow. And praised be ... ${ }^{117}$

110 Adorno, 'The Meaning of Working Through the Past', n 42 above, 5.

111 Walter Benjamin, justifying his decision not to leave Europe in 1936, discussed by Peter Szondi in his 'Hope in the Past', n 109 above, 33.

112 De Courant/Nieuws Van Den Dag (2 February 1942).

113 Pope Francis's comments on Europe's failings are in the same vein, 'Pope Francis complains of “haggard” Europe in Strasbourg' BBC News (25 November 2014), http://www.bbc.co.uk/news/worldeurope-30180667.

114 Douglas-Scott, 'Europe's Constitutional Mosaic', n 69 above.

115 ibid.

116 Adorno, 'The Meaning of Working Through the Past', n 42 above, 18.

117 Schwarz-Bart, The Last of the Just, n 52 above, 383. 